\title{
Psychosocial Strategies, Debasing Gender- Based Violence in Nigeria
}

\author{
Olusegun, G. F.( Ph.D) ${ }^{1} \quad$ Olatubosun,S.M.( Ph.D) ${ }^{2} \quad$ Adedokun, M.O. (Ph.D) ${ }^{3} \quad$ Abiodun, E.O. ( Ph.D) $)^{4}$ \\ 1.Department of Guidance and Counselling, Ekiti State University, ADO EKITI \\ 2.Department of Science Education, Ekiti State University, ADO EKITI \\ 3.Department of Adult Education and Community Development, Ekiti State University,ADO EKITI \\ 4.Department of Social Sciences, Ekiti State University, ADO EKITI
}

\begin{abstract}
This paper examines Gender -based violence, a violence directed against humans based on their gender which occurs as a result of the normative role expectations associated with each gender and there seems to be unequal relationship between the two genders within the context of each society (Hynes Cardozo,2000). It encompass a large variety of crimes like harassment, threat of rape, rape, forced marriage, human trafficking, female genital mutilation, child abuse Different forms of violence were perpetrated against females in both public and private spheres of life, at any time of their life span cursing harmful and damaging consequences in their lives. The terrifying acts inflicted on females caused by traditional held believes and socially constructed behaviours attributed to gender thus affects women in disproportionate manner. The study investigated gender- based violence Nigerian society and the strategy to debase the unfair act.
\end{abstract}

Keywords: Gender,violence,forms,effects,strategy,society.

DOI: $10.7176 /$ RHSS/9-22-04

Publication date: November $30^{\text {th }} 2019$

\section{Introduction}

Women are very significant in the society, any society with paucity of women roles, the impact will be greatly felt, yet this category of gender were treated shabbily as a second hand citizen. This threat of violence has created much fear in women and thus hinder them to exercise their human right. The epidemic of gender based violence has become a national phenomenon, eaten deep into the lives of female. These analogues have their roles in maladjusted behaviours demonstrated by males on females. It appears that there is power imbalanced between boys and girls, man and woman in the society as stressed by Krantz, Gunilla \$ Claudia (2015) where men and his manly role are inflated. Gender ascribed roles imposed on women seems to influence gender- based violence experienced that entrenched in the belief that females should be restricted to domestic activities, living to satisfy mens sexual urge of husbands without resistance. The weak institutional arrangements that addressed consequences of sexual violence has aggravated the unfair treatment of the victims showing direct reflections of the ways in which society regards women. Danet \& Brenda, 2008), stressed that violence against women is one of the crucial social mechanisms by which women are forced into a subordinate position compared with men". ascribed society whereby female victim resistance is percieved by the perpetrator as an insult to his manhood.(WHO, 2013). The double standard is evident when girls are judged for engaging in premarital sex and boys are rewarded for engaging in such act and been rewarded for the undesired sexual behaviour.

\section{Concept of Gender Based Violence}

The term "gender based violence" reflects the idea that violence often serves to maintain structural gender inequalities against all categories of females either young or old. Gender -based violence denotes forceful acts of behaviour against all human gender, a harm inflicted upon individuals and groups that is connected to narrative understanding of their gender particularly females. Gender based vioence could be verbal or non-verbal, oral or written, physical or non-physical, active /passive, public/ private, institution /individual. It could be regarded as the general tern used to capture all the violence acts that occurs as a result of the social and cultural normative role expectations associated with each gender. According to Khawaja, (2014), gender - based violence against women is defined as a "violence that is directed against a woman because she is a woman or that affects women disproportionately.

According to Schwartz and Bilsky, (2017), gender based violence is a phenomenon deeply rooted in gender inequality, and continues to be one of the most notable human rights violations within all societies. These scholars stressed that gender -based violence involves men and women, in which the females is usually the target which couls be attributed to the unequal power relationships netween men and women. This implies that gender based violence is a violence directed against a person because of their gender. It is "a manifestation of the historically unequal power relations between men and women, which have led to domination over and discrimination against women by men and to the prevention of women's full advancement.

Gender -based violence encompass a large variety of crimes such as rape, sexual harassment, stalking, 
human trafficking, domestic abuse, genital mutilation, and forced prostitution, force marriage to mention a few.( Ericand Robinson, 2008). , Violence against females sexuality lie in the social structure characterized by severe inequality in which there is male dominance and the female exploited, (Ang, 2008). Nevertheless, it should be noted without any gain saying that the term gender violence has a strong connoitation with violence and driven by unprecedented biases and hatred against a certain group of people name females.

Men,s wield of power over female often result to more cruel acts to supress their status in the society and this permissive acts on the part men as stressed by Hall, 2010), has been resulting to an engraving consequences like physical, psychological and emotional harm in the lives of women because they are women. There is need to address the social and cultural issues that encourage violence as part of masculinity. An ending solution that will enhance total well- being is germane.

Different Forms Of violence Against Females

Violence against females could be classified under the following subheadings.; Physical, sexual and psychological.

It encompass the following.;

i.Sensual harrasment, unwanted sexual advances in schools and at work. It also includes psychological

violence like humiliation and unwantd comments.

ii.Sexual abuse and rape of females of all categories.

iii.Abuse of females marital life like, force marriage, force prostitution and trafficking, force abortion, breast flattening, bride kidnaping, honour killing,

iv.Force acquisition like, sons preference, witchcraft especially if the husband dies, dowry violence,

v.Marital rape and sexual abuse of female children in the household. Early child marriage, force marriage, virginity testing, force pregnancy, force sterilization, force abortion, force feeding, breast ironing and flattening and dowry violence.

vi.Trafficking in human beings, sexual slavery, sexual exploitation and forced prostitution.

vii. Force exposure to pornography

viii. Female genital mutilation

Battering / bulling by guidians and sexual partner.

ix. Mistreatment of females especially widows, beaten, sheating on them,denial of parents and husband financial resources, denial of freedom, properties, good education and decision making.

All these these fairless acts has been resulting to short and long term consequences in the life of females physically, socially, financially and psychological consequencies. The consequence could be immediate as well as latent and can last for years after the initial abuse. Such as poor health, impairment, untimely death, Sustenance of injury, involvement in risky behaviours like, alcohol, drug addiction and smoking, That could result to cardiovascular disorders, cancers, depression, diabetes and HIV/AIDS, Violence may beget violence, Economic effects, Effects on the society, Psychological trauma, Negative impact on children exposure to violence in the family and Impact of trauma with physical injury, illness, psychotics symptom, economic and so on. Schwartz and Bilsky, (2017). Gender Bsed Violence could violate women's right, such as right to life, right not to subject to torture or cruel. Inhuman treatment and punishment, right to equal protection under law, right to equality in the family, right to highest standard attainable of physical and mental health.

Following strategies were highlighted to debase further occourrence of Violence against females in Nigerian society.;

1. Gender norms and social constructs that promotes Gender based must be review and eradicated.

2. Investigate the root cause of the violence experience

3. Government should formulate policy on gender based violence and attach appropriate punishment.

4. The policy formulated must be strictly implimented with immediate judgement by law enforcement agents.

5. Victims should be encouraged to report their violence experience to law enforcement agents.

6. Reported cases of GBV should not be handled with levity.

7. School-based programmes to prevent sexual abuse by teaching children to recognize and avoid potentially sexually abusive situations, such as, dating relations.

8. Prevention programmes to reduce access to alcohol, illegal drugs and guns.

9. Urban renewal projects such as business improvement as effort made to reduces youth violence and combine microfinance with gender equality training.

10. Effective prevention programmes to support parents and teach positive parenting skills, and care of children and families to reduce the risk of Promote communication and relationship skills within communities' cultural gender norms.

11. Strategies that could prevent elder maltreatment action against their children and wards.

12. Primary health prevention - approaches that aim to prevent violence before it occurs, Secondary health 
prevention - approaches that focus on the more immediate responses to violence, such as pre-hospital care, emergency services or treatment for sexually transmitted infections with violence.

13. Public health approach in defining the problem conceptually and numerically, using statistics that accurately describe the nature and scale of violence.

14. Government and non-governmental agents should continue to organise effective programmes that could eradicate GBVin the society.

15. Gender equality must be promoted to guide against GBV.

16. Professional counsellors should intensify efforts to educate all and sundry. in the society on the evil effects on GBV victim's total -wellbeing.

17. Government and non-government organization should not relent in their campaign against violence acts in the society.

18. Victims should be empowered economically.

\section{Conclusion}

Gender based violence underscore the absence of any choice available to the victim that does not involve severe, physical and social consequences. The unequal distribution of power between men and women constitutes the vast majority of persons affected by GBV with majourity of perpetrators being males. It could be concluded that sexual violence inflicted on females by males are of different forms. It is concluded in this study that the effects of the violence experienced by women often result to damaging consequences and thus affects virtually every sector of the society. Approaches and strategies to curb the cruel experience is employed to debase further occurrence and this will empower females to exercise their human rights and be able to contribute to the social, economic, and political development of the society.

\section{REFERENCES}

1. Danet \& Brenda (2018) Text as mask: gender, play, and Performance on the internet. In S, Jones(Ed).Cybersociety 2.0(129-158).

2. Hynes, M., \& Cardozo, B.L. (2000). Sexual violence against refuge women. Journal of Women,s Health \& Gender-Based Medicine, 9,819-823.

3. Khawaja, M. (2014). Domestic violence in refugee camps in Jordan.International Journal of Gynaecology \& Obstertric, 86, 67-69.

4. Krantz, Gunilla, Garcia-Moreno, Claudia (2015). 'Violence against women'. Journal of Epidemiology and Community Health, BMJ Group. 59(10):818-821.

5. Schwartz, S.H. \& w. Bilsky (2017). Towards a universal Psychology Structure of Human values. Journal of personality and social psychology, 53. 550-562.

6. Stroller, R. J. (2012). The "bedrock' of masculinity and feminity: Bisexuality. Archives of general Psychiatry, 26, 207-212. Google Scholar. 